\title{
Disinfection Room: Cleaning Room
}

\begin{abstract}
The disinfection room is central to all operations and is a multifunctional room. Here, all contaminants and organic materials are taken care of and removed. Contaminated textiles are sorted and ordinary waste from infectious waste. Used syringes and other stabbing/cutting waste, glass, etc. are collected as hazardous waste. Used wheelchairs and other major patient aids are usually washed here. The bedpan, urine bottles, etc. are disinfected in the decontaminator. The room has a large load of dirt and microbial agents where the personnel may perform many space-demanding tasks. A large and efficient area with good separation between clean and unclean work tasks, good ventilation and negative pressure ventilation and good methods for cleaning and disinfection are necessary. The following chapter is focused on areal and outfit of the disinfection room to avoid transmittance of infections between patients, personal and environment.
\end{abstract}

\section{Keywords}

Disinfection room - Waste room · Used equipment · Decontaminator · Instrument washing-machine $\cdot$ Bedpans $\cdot$ Urine bottles

\subsection{Purpose}

To protect patients, personnel and the environment against infection [1-4].

\subsection{Comprise}

All staff who use the disinfection room. All equipment, textiles, waste, etc., which are treated/stored/collected and sorted in the disinfection room. 


\subsection{Responsibility}

The hospital's management ensures that disinfection rooms are adapted to the function and patient beds of the individual department. The disinfection unit may, according to area, outfit, structure and routines, protect personnel, patients and environment against infections [1]. Written procedures for work and control in disinfection rooms shall be available.

The department's management complies with hygienic guidelines, ensures that staff are educated and reports to the director if the disinfection system may present a risk to patients and personnel.

The personnel follow guidelines for personal and general hygiene and procedures for the disinfection room.

\subsection{Practical Measures [5, 6]}

\subsubsection{Location, Size and Design of the Disinfection Room}

- The disinfection room must be easily accessible, centrally located in the department/ward and with direct access from the corridor. Do not throughput to the corridor because of the fire department's rules.

- The disinfection room must have a negative air pressure so that airborne contaminants are kept mostly within the room. Keep the door closed. Keep all throughput openings closed. The ventilation should be good, at least 8 fresh air exchanges/hour.

- Separate extracts/hoods may be established if using special chemical disinfectants.

- Large enough area for the department/patient beds activities; at least $3 \mathrm{~m}$ between clean and unclean sides (due to splash and aerosol formation). The area required is usually $18-20 \mathrm{~m}$ [2]. The work must be carried out efficiently and risk-free even if the doors to the decontaminator are opened.

- Floors and walls must withstand strong disinfectants and frequent cleaning.

- Drain in the floor may be correct.

- There should be a large enough area for cleaning of wheelchairs, aids, etc., if the hospital does not have a separate cleaning facility or system for large equipment between patients.

- The disinfection unit may have its own clean storage room for cleaned and readyto-use bedpans, urine bottles, flower glasses, cleaned walking chairs and other noncritical aids. This store room should not be used for clean textiles, sterile equipment, etc.!

\subsubsection{Equipment and Fixtures}

- Sink with single-grip battery and with long touchless arm.

- There should be plenty of space for one to two machines (decontaminator, instrument washing machine) with the position of the soap system well above the floor. 
The area requirement for machines may be approximately 4-6 m [2]. It should be easy to carry out cleaning around/under the machines.

- Hand washbasin with soap and hand disinfectant at the door with plenty of space for washing and tiled wall down to the floor. Fall height of the water should not exceed $30 \mathrm{~cm}$ (avoid splash).

- The hot water should be at least $75{ }^{\circ} \mathrm{C}$, after a few minutes. Check with thermometer a few times a year. Discuss the use of electronic wash at fixed temperature because of risk of increased growth of gram-negative bacteria such as Pseudomonas aeruginosa and legionella due to low temperature [7-11].

- Hand disinfectants, preferably automatic dispenser.

- Collecting racks for laundry, waste, special waste, etc. (unclean side)—area requirement approximately6 m [2]. Racks with pedal lock.

- Benches for unloading equipment for clean and unclean side.

- Separate washbasin with large rinsing basin-possibly two, depending on usage needs and other benches for storage.

- Throughput closet for optional drying after wash in a drying cabinet. Note that the doors in the drying cabinet must not stand open! In such cases, the negative air pressure may disappear, and possibly infectious agents may spread to other rooms via the air.

- Lockable closet for disinfectants.

- Cabinet for storage of clean equipment for waste management.

- All important procedures must be in writing in protected, washable plastic.

\subsubsection{Control Functions}

- Daily check that machines are working properly. Check daily that there is soap on the container of the decontaminator. Report to medical-technical department if leakage, suspicion of low temperature or if the equipment is unclean after washing.

- Daily check that all waste, including infectious, cans with cutting/stinging contaminants and the laundry, is properly handled and removed by appointment and before it gets overcrowded.

- Unauthorized personnel are not allowed to stay in the room. No access for relatives or patients.

- Daily check of cleaning of floors and benches. Daily washing of floors, surfaces and around wash all day of the week; see Chap. 65 on cleaning of rooms.

- Equipment not belonging to the disinfection room system shall not be placed on the disinfection room.

- Temperature control of decontaminator and instrument washing machine every 14days. Register in the list.

\subsection{Background Information}

To the disinfection room, a number of potentially infectious agents are brought daily, which — if not properly treated-exposes personnel and patients to infection. 
Microbiological agents brought into the disinfection room can cause serious infections via:

- Blood-borne infection: hepatitis A, B, C, D, E, HIV, HTLV, etc.

- Contact-transmitted infection: Staphylococcus aureus, streptococci, Salmonella, Shigella, Clostridium difficile, hepatitis A, norovirus, rotavirus, etc.

- Airborne infection (including contact): tuberculosis, MRSA and other resistant bacteria, influenza, respiratory syncytial virus-RSV, norovirus, sapovirus, bocavirus, coronavirus, etc.

\subsubsection{Good Hygiene Prevents Infection Risk}

In the disinfection room, both clean and unclean material is treated, often at the same time during a busy day in the ward. It is important to distinguish between clean and unclean sides of the room and carry out good hand hygiene between work tasks. Risk processes that cause splash/contamination of biological material must be avoided. Everything must be treated with care. No contamination or misunderstanding may occur that exposes personnel or patients to infection risk.

See also Chap. 66 on disinfection.

\section{References}

1. The Norwegian State Drug Control: chemical disinfectants for technical use in health- and nursing. Oslo: Statens Legemiddelverk, Sosial- og Helsedepartementet; 2012.

2. Ministry of Labor and Administration. Regulations on protection against exposure to biological factors (bacteria, viruses, fungi and more) in the workplace. FOR OSLO: 1997-12-19 nr.1322.

3. Sehulster LM, Chinn RYW, Ardunio MJ, et al. Guidelines for environmental infection control in health-care facilities. CDC. MMWR. 2003;52:1-42.

4. Rutala WA, Weber DJ. Disinfection, sterilization, and control of hospital waste. In: Mandell, Douglas, and Bennets principles and practice of infectious diseases, vol. 2. Philadelphia: Elsevier Churchill Livingstone; 2015. p. 3294-309.

5. Hochlin K, Solheim N, Rasch M, Laugerud F, Andersen BM. Disinfection room/cleaning room - fitting and use. In: Handbook in hygiene and infection control for hospitals. Oslo: Ullevål University Hospital; 2003. p. 470-3.

6. Laugerud F, Hochlin K, Rasch M, Andersen BM. Disinfection room/cleaning room - fitting and use. In: Handbook in hygiene and infection control for hospitals. Oslo: Ullevål University Hospital; 2008. p. 650-3.

7. Charron D, Bedard E, Lalancette C, Laferriere C, Prevost M. Impact of electronic faucets and water quality on the occurrence of Pseudomonas aeruginosa in water: a multi-hospital study. Infect Control Hosp Epidemiol. 2015;36:311-9.

8. Andersen BM. Legionella. In: In: microbiology and infection control. Handbook in hygiene and infection control part 1. Bergen: Fagbokforlaget; 2014. p. 116-9. 
9. Moore G, Walker J. Presence and control of Legionella pneumophilia and Pseudomonas aeruginosa biofilms in hospital water systems. In: Percival SL, Williams DW, Randle J, Coioper T, editors. Biofilms in infection prevention and control. Boston: Academic; 2014. p. 311-37.

10. Assadian O, El-Madani N, Seper E, et al. Sensor-operated faucets: a possible source of nosocomial infection? Infect Control Hosp Epidemiol. 2002;23:44-6.

11. Andersen BM. Gram-negative rod bacteria in the intestine and/or environment. In: Microbiology and infection control. Handbook in hygiene and infection control part 1. Bergen: Fagbokforlaget; 2014. p. 85-94. 